\title{
WPŁYW UKŁADU HYDRAULICZNEGO ZBIORNIKA NA WYMAGANĄ POJEMNOŚĆ UŻYTKOWĄ UKŁADU ZBIORNIKÓW RETENCYJNYCH W KANALIZACJI
}

\begin{abstract}
Celem artykułu jest określenie wpływu zastosowanego układu hydraulicznego w zbiorniku retencyjnym zlokalizowanym na końcu zlewni położonej wyżej na wymaganą pojemność użytkową wielokomorowego zbiornika retencyjnego położonego na końcu zlewni usytuowanej niżej. Symulacje przepływu i akumulacji ścieków wykonano w zlewni modelowej korzystając z programu hydrodynamicznego SWMM 5.1. Uzyskane wyniki badań modelowych wykazały, że układ hydrauliczny zbiornika $Z R 1$ zlokalizowanego wyżej na sieci ma decydujący wpływ na wyznaczenie wymaganej kubatury użytkowej zbiornika retencyjnego $Z R 2$ usytuowanego na niżej położonej sieci kanalizacyjnej. Na podstawie wyników symulacji komputerowych potwierdzono, że zbiornik $Z R 2$ ma najmniejszą pojemność użytkową, gdy zbiornik górny $Z R 1$ cechuje się jednokomorowym układem hydraulicznym. Uzyskane różnice w pojemności retencyjnej zbiornika dolnego $Z R 2$ sięgają kilkudziesięciu procent, a w skrajnych przypadkach znacznie więcej. Ustalono zależności pojemności zbiorników zaobserwowane dla szerokiego zakresu zmiennego natężenia odpływu ścieków ze zbiorników retencyjnych $Z R 1$ i $Z R 2$.
\end{abstract}

Słowa kluczowe: kanalizacja deszczowa, zbiorniki retencyjne, układy hydrauliczne, wymiarowanie

\section{Wstęp}

Zbiorniki retencyjne stanowią obecnie podstawowy element sieci kanalizacyjnych dowolnego systemu, działającego w układzie grawitacyjnym [8, 9]. Ze względu na swoje przeznaczenie mogą pełnić różne funkcje. Ich zastosowanie

\footnotetext{
${ }^{1}$ Autor do korespondencji / corresponding author: Józef Dziopak, Politechnika Rzeszowska, Zakład Infrastruktury i Ekorozwoju, Wydział Budownictwa, Inżynierii Środowiska i Architektury, 35-959 Rzeszów, al. Powstańców Warszawy 6, tel. +48 (017) 865 1817, jdziopak@ @rz.edu.pl 2 Mariusz Starzec, Politechnika Rzeszowska, Zakład Infrastruktury i Ekorozwoju, Wydział Budownictwa, Inżynierii Środowiska i Architektury, 35-959 Rzeszów, al. Powstańców Warszawy 6, tel. +48 (017) 743 2409, mstarzec1990@ prz.edu.pl
} 
umożliwia między innymi odciążenie hydrauliczne sieci kanalizacyjnej i obiektów oraz urządzeń z nią współdziałających [2].

Niezależnie od stawianego zadania w systemie, główną rolą zbiorników retencyjnych jest przechwycenie nadmiaru ścieków i ich odprowadzanie w określonej ilości i czasie [3]. Ich wymiarowanie wymusza każdorazowo ustalanie wymaganej kubatury użytkowej, którą wyznacza się w oparciu o bilans ścieków na dopływie i odpływie w fazie jego napełniania. Szukana pojemność retencyjna jest równa polu powierzchni pomiędzy krzywymi opisującymi hydrogramy natężenia dopływu i odpływu ścieków w czasie ze zbiornika podczas występowania deszczu miarodajnego, ustalanego na podstawie obliczeń [5, 7].

Inaczej niż z jednym zbiornikiem wymiaruje się kanalizację deszczową współdziałającą z dwoma lub więcej zbiornikami retencyjnymi. Przy wyznaczaniu pojemności użytkowej układu zbiorników retencyjnych należy uwzględniać wzajemne oddziaływanie zbiorników względem siebie korzystając z modelowania hydrodynamicznego do symulowania przepływów w sieci łączącej zbiorniki. Na wartość dopływających ścieków do zbiornika retencyjnego zlokalizowanego niżej na sieci kanalizacyjnej, oprócz wielkości spływu ze zlewni położonej pomiędzy sąsiadującymi zbiornikami ma wpływ ilość ścieków odpływających w czasie z najbliższych zbiorników retencyjnych położonych wyżej na sieci kanalizacyjnej. Ilość ścieków odpływających ze zbiornika retencyjnego jest bezpośrednio uzależniona od przyjętego układu hydraulicznego. $\mathrm{Z}$ tego też względu sprawność hydrauliczna zbiornika znajdującego się wyżej wpływa bezpośrednio w różnym stopniu na wymaganą pojemność retencyjną zbiornika znajdującego się niżej na sieci.

Zbiorniki grawitacyjne jednokomorowe charakteryzują się bardzo zróżnicowanym odpływem w czasie trwania procesu akumulacji ścieków. Maksymalny odpływu ścieków jest chwilowy i to wyłącznie przy całkowitym napełnieniu zbiornika i ta cecha decyduje o ich małej sprawności hydraulicznej. Fakt ten wymusza zarezerwowanie największej kubatury użytkowej w stosunku do innych typów zbiorników retencyjnych [6].

Zbiorniki grawitacyjne wielokomorowe posiadają dużo większą sprawność hydrauliczną $\mathrm{w}$ porównaniu do zbiornika jednokomorowego. W sprzyjających warunkach różnice w wymaganej pojemności użytkowej mogą wynosić nawet ponad 40\% [3]. Zbiornik wielokomorowy składa się z przynajmniej dwóch komór. Pierwsza z nich, komora przepływowa służy do utrzymywania maksymalnej przyjętej wartości natężenia odpływu ścieków praktycznie w całym okresie akumulacji. Pozostałe komory jako akumulacyjne mają za zadanie zmagazynowanie nadmiaru ścieków dopływających do zbiornika.

Najwyższą sprawność hydrauliczną posiadają zbiorniki grawitacyjno-pompowe i grawitacyjno-podciśnieniowe [4]. W tego typu konstrukcjach kubaturowych w razie potrzeby możliwe jest utrzymywanie maksymalnej przyjętej wartości natężenia odpływu ścieków, zarówno w procesie akumulacji, jak i w czasie opróżniania zbiornika. 


\section{Przyjęty wariant obliczeniowy}

W ramach prowadzonych badań podjęto próbę określenia stopnia oddziaływania układu hydraulicznego zbiornika retencyjnego $Z R 1$ położonego wyżej na końcu zlewni $F 1$ na wymaganą pojemność użytkową zbiornika wielokomorowego $Z R 2$ usytuowanego niżej na końcu zlewni $F 2$ na kanalizacji deszczowej.

$\mathrm{W}$ analizie przyjęto trzy odmienne układy hydrauliczne zbiornika retencyjnego $Z R 1$, tj. grawitacyjny jednokomorowy $Z K$, grawitacyjny wielokomorowy $Z W G$ i grawitacyjno-pompowy ZGP. Położenie zbiorników retencyjnych względem siebie w zlewniach przedstawiono na rysunku 1.

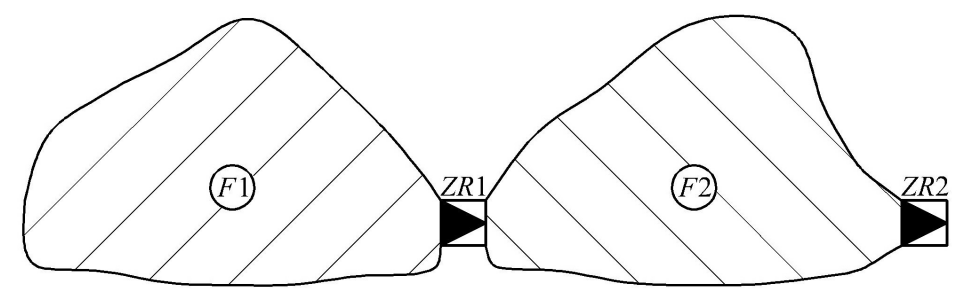

Rys. 1. Schematy i lokalizacja zbiorników retencyjnych w zlewniach kanalizacyjnych przyjętych do analizy: $Z R 1$ - zbiornik retencyjny położony poniżej zlewni $F 1$ ( $Z K$ - zbiornik grawitacyjny jednokomorowy, $Z W$ - zbiornik grawitacyjny wielokomorowy, $Z G P$ - zbiornik grawitacyjno-pompowy), $Z R 2$ - wielokomorowy zbiornik retencyjny położony poniżej zlewni $F 2, F 1$ - górna zlewnia odwadniana, $F 2$ - dolna zlewnia odwadniana

Fig. 1. Schemes and location of storage reservoirs in the catchment used for analysis: $Z R 1$ - reservoir situated below the catchment $F 1$ ( $Z K$ - one-chamber gravitational reservoir, $Z W$ - gravitational multi-chamber reservoir, $Z G P$ gravity-pump multi-chamber reservoir), $Z R 2$ - gravitational multi-chamber reservoir situated below the catchment $F 2$, $F 1$ - upper catchment, $F 2$ - lower catchment

Powierzchnie zredukowane zlewni $F 1$ i $F 2$ wynoszą po 15,0 ha każda. Do określenia jednostkowego natężenia miarodajnego przepływu ścieków deszczowych w kanalizacji deszczowej skorzystano z formuły Błaszczyka [1], która określa zależność pomiędzy intensywnością opadu a czasem jego trwania:

$$
q_{d m}=\frac{6,631 \cdot \sqrt[3]{H^{2} \cdot c}}{t_{d}^{2 / 3}}
$$

gdzie: $q_{d m}-$ jednostkowe natężenie deszczu, $\mathrm{dm}^{3} /(\mathrm{s} \cdot \mathrm{ha})$;

$H$ - wysokość średniego opadu rocznego, $\mathrm{mm} /$ rok;

$c$ - częstość występowania opadu, lata;

$t_{d}-$ czas trwania opadu, min.

W obliczeniach przyjęto wysokość średniego opadu rocznego $H=600 \mathrm{~mm}$ i częstość występowania opadu o wartości $c=2$ lata. Zgodnie z założeniem metody granicznych natężeń $(M G N)$ przyjęto, że opad deszczu charakteryzuje się 
stałą intensywnością w czasie jego trwania i występuje jednocześnie na całym obszarze badanych zlewni $F 1$ i $F 2$.

Ustalono, że w zbiorniku $Z R 1$ maksymalne natężenie odpływu ścieków $Q O_{Z R 1}$ przyjmuje trzy wartości, odpowiednio $150,450 \mathrm{i} 750 \mathrm{dm}^{3} / \mathrm{s}$. W przypadku zbiornika $Z R 2$, analizę przeprowadzono przyjmując kolejno osiem różnych maksymalnych natężeń odpływu ścieków $Q O_{Z R 2}$ o wartościach $250,350,450,550$, $650,750,850$ i $950 \mathrm{dm}^{3} / \mathrm{s}$. Przy takich założeniach otrzymano dwadzieścia cztery różne warianty obliczeniowe obciążenia hydraulicznego sieci i zbiorników retencyjnych, które poddano analizie hydraulicznej korzystając z programu hydrodynamicznego SWMM 5.1.

Układ hydrauliczny zbiornika działającego jako grawitacyjnego wielokomorowego i grawitacyjno-pompowego w programie SWMM 5.1 osiągnięto przez zastosowanie szeregowego układu dwóch zbiorników jednokomorowych. Pierwszy zbiornik pełni funkcję komory przepływowej, natomiast drugi przejmuje rolę komory akumulacyjnej. Transport ścieków z komór przepływowej do akumulacyjnej w czasie napełniania opisano za pomocą funkcji Outlet. Odprowadzenie ścieków z komory akumulacyjnej do przepływowej podczas opróżniania odwzorowano korzystając z funkcji Weir. W przypadku zbiornika jednokomorowego układ hydrauliczny odzwierciedla jeden zbiornik, który pełni funkcję komory przepływowej i akumulacyjnej.

Odpływ ścieków z komory akumulacyjnej zbiornika wielokomorowego odbywa się wyłącznie w sytuacji, kiedy poziom ścieków w tej komorze jest wyższy niż w komorze przepływowej. W przypadku zbiornika grawitacyjno- pompowego przyjęto, że jako pierwsza opróżniana jest górna komora akumulacyjna, która wcześniej jest napełniana pompowo.

\section{Analiza wyników symulacji}

\subsection{Układ hydrauliczny a wymagana pojemność użytkowa zbiornika}

Oddziaływanie zbiorników retencyjnych zachodzi w przypadku ich lokalizacji na trasie przepływu ścieków. W celu właściwego zwymiarowania niżej położonego zbiornika retencyjnego $Z R 2$ należy, oprócz ustalenia wielkości przepływu ścieków deszczowych ze zlewni $F 2$ prawidłowo wyznaczyć odpływ ścieków ze zbiornika retencyjnego $Z R 1$. Usytuowanie zbiorników $Z R 1$ i $Z R 2$ na sieci wykazało ich wzajemne oddziaływanie hydrauliczne. W pierwszej kolejności wyznaczono wymaganą pojemność użytkową zbiornika $Z R 1$, ustalając jego wymaganą pojemność uwzględniając wszystkie przyjęte warianty projektowe i trzy odmienne układy hydrauliczne zbiornika ( $Z K, Z W G$ i $Z G P)$. Wyniki obliczeń zamieszczono w tabeli 1.

Analizując dane uzyskane z badań symulacyjnych (tabela 1) należy postawić tezę [3], że największą wymaganą pojemność użytkową osiąga zbiornik $Z R 1$, jeżeli ma układ jednokomorowy. Kolejny raz potwierdzono również [3], że 
czas miarodajny do jego wymiarowania przyjmuje najwyższą wartość. Wspomniane wyżej zależności obserwuje się przy wszystkich założonych wartościach maksymalnego natężenia odpływu ścieków $Q O_{Z R 1}$ ze zbiornika $Z K$.

Tabela 1. Wymagane pojemności użytkowe zbiornika retencyjnego $Z R 1$ przy uwzględnieniu jego różnych układów hydraulicznych

Table 1. Required useable cubic capacity of storage reservoir $Z R 1$ for different hydraulic models

\begin{tabular}{|c|c|c|c|c|c|c|}
\hline \multirow{3}{*}{$\begin{array}{l}\text { Maksymalne } \\
\text { natężenie } \\
\text { odpływu } \\
\text { ścieków } \\
\text { ze zbiornika } \\
Z R 1, Q O_{Z R 1}\end{array}$} & \multicolumn{6}{|c|}{$\begin{array}{c}\text { Użytkowa pojemność retencyjna zbiornika } Z R 1 \text { przy jego różnym układzie } \\
\text { hydraulicznym }\end{array}$} \\
\hline & \multicolumn{2}{|c|}{$\begin{array}{c}\text { Grawitacyjny } \\
\text { jednokomorowy (1) } \\
Z K\end{array}$} & \multicolumn{2}{|c|}{$\begin{array}{c}\text { Grawitacyjny } \\
\text { wielokomorowy (2) } \\
Z W G\end{array}$} & \multicolumn{2}{|c|}{$\begin{array}{c}\text { Grawitacyjno- } \\
\text {-pompowy } \\
\text { wielokomorowy (3) } \\
Z W G P\end{array}$} \\
\hline & $\begin{array}{l}V_{Z R 1} \\
(Z K)\end{array}$ & $\begin{array}{c}\text { Czas } \\
\text { krytyczny, } \\
T M K\end{array}$ & $\begin{array}{c}V_{Z R 1} \\
(Z W G)\end{array}$ & $\begin{array}{c}\text { Czas } \\
\text { krytyczny, } \\
T M W\end{array}$ & $\begin{array}{c}V_{Z R 1} \\
(Z W G P)\end{array}$ & $\begin{array}{c}\text { Czas } \\
\text { krytyczny, } \\
T M W P\end{array}$ \\
\hline$\left[\mathrm{dm}^{3} / \mathrm{s}\right]$ & {$\left[\mathrm{m}^{3}\right]$} & [min] & {$\left[\mathrm{m}^{3}\right]$} & [min] & {$\left[\mathrm{m}^{3}\right]$} & {$[\min ]$} \\
\hline 150 & 1783,05 & 161 & 1323,07 & 104 & 1323,07 & 104 \\
\hline 450 & 782,15 & 41 & 417,56 & 30 & 417,56 & 30 \\
\hline 750 & 367,28 & 24 & 110,04 & 19 & 110,04 & 19 \\
\hline
\end{tabular}

Odpływ ścieków ze zbiorników retencyjnych $Z R 1$ i $Z R 2$ odbywa się w fazach ich akumulacji i opróżniania. Faza akumulacji ścieków występuje, gdy chwilowy dopływ strumienia ścieków do zbiornika jest większy niż ich odpływ. Natomiast faza opróżniania tych zbiorników występuje w sytuacji odwrotnej. Ponieważ odpływ ścieków ze zbiornika $Z R 1$ sumuje się z odpływem ścieków ze zlewni $F 2$ znajdującej się pomiędzy nimi, z tego powodu wpływ na wymaganą pojemność zbiornika $Z R 2$ ma zastosowany układ hydrauliczny zbiornika $Z R 1$.

W następnym etapie badań sprawdzono wpływ różnego układu hydraulicznego zbiornika retencyjnego $Z R 1$ na wymaganą pojemność zbiornika wielokomorowego $Z R 2$. Wyniki przeprowadzonych symulacji przy założonych wartościach maksymalnego natężenia odpływu ścieków ze zbiorników $Z R 1$ i $Z R 2$ przedstawiono w tabelach 2, 3 i 4 .

Przeprowadzone symulacje wykazały, że przyjęty układ hydrauliczny zbiornika $Z R 1$ ma decydujący wpływ ma wymaganą (krytyczną) pojemność użytkową zbiornika retencyjnego $Z R 2$. Analizując dane zawarte w tabelach 2,3 i 4 ustalono, że zbiornik retencyjny $Z R 2$ wymaga zarezerwowania najmniejszej pojemności użytkowej, jeżeli zbiornik retencyjny $Z R 1$ działa w układzie jednokomorowym (1).

Znacznie większą pojemność użytkową zbiornik retencyjny $Z R 2$ wymaga w przypadku zastosowania w zbiorniku $Z R 1$ układu wielokomorowego działającego w sposób grawitacyjny (2). 
Tabela 2. Wymagana pojemność użytkowa zbiornika retencyjnego $Z R 2$ przy odpływie ścieków ze zbiornika $Z R 1$ o $Q O_{Z R 1}=150 \mathrm{dm}^{3} / \mathrm{s}$

Table 2. Required useable cubic capacity of storage reservoir $Z R 2$ at outflow from reservoir $Z R 1$ $Q O_{Z R 1}=150 \mathrm{dm}^{3} / \mathrm{s}$

\begin{tabular}{|c|c|c|c|c|c|c|}
\hline \multirow{2}{*}{$\begin{array}{c}\text { Maksymalne } \\
\text { natężenie } \\
\text { odpływu } \\
\text { ścieków } \\
\text { ze zbiornika } \\
Z R 2, Q O_{Z R 2}\end{array}$} & \multicolumn{3}{|c|}{$\begin{array}{c}\text { Użytkowa pojemność retencyjna zbiornika ZR2 przy różnym układzie } \\
\text { hydraulicznym zbiornika retencyjnego ZR1 }\end{array}$} \\
\cline { 2 - 7 } & \multicolumn{2}{|c|}{$\begin{array}{c}\text { Grawitacyjny } \\
\text { jednokomowy (1) }\end{array}$} & \multicolumn{2}{c|}{$\begin{array}{c}\text { Grawitacyjny } \\
\text { wielokomorowy (2) } \\
Z W G\end{array}$} & $\begin{array}{c}\text { Grawitacyjno- } \\
\text {-pompowy } \\
\text { wielokomorowy (3) } \\
Z W G P\end{array}$ \\
\cline { 2 - 8 } & $\begin{array}{c}V_{Z R 1} \\
(Z K)\end{array}$ & $\begin{array}{c}\text { Czas } \\
\text { krytyczny, } \\
T M K\end{array}$ & $\begin{array}{c}V_{Z R 1} \\
(Z W G)\end{array}$ & $\begin{array}{c}\text { Czas } \\
\text { krytyczny, } \\
T M W\end{array}$ & $\begin{array}{c}V_{Z R 1} \\
(Z W G P)\end{array}$ & $\begin{array}{c}\text { Czas } \\
\text { krytyczny, } \\
T M W P\end{array}$ \\
\hline$\left[\mathrm{dm}^{3} / \mathrm{s}\right]$ & {$\left[\mathrm{m}^{3}\right]$} & {$[\mathrm{min}]$} & {$\left[\mathrm{m}^{3}\right]$} & {$[\mathrm{min}]$} & {$\left[\mathrm{m}^{3}\right]$} & {$[\mathrm{min}]$} \\
\hline 950 & 0 & - & 44,44 & 19 & 46,44 & 19 \\
\hline 850 & 25,8 & 19 & 106,43 & 22 & 108,8 & 22 \\
\hline 750 & 83,37 & 22 & 193,33 & 25 & 196,07 & 25 \\
\hline 650 & 168,96 & 25 & 308,98 & 30 & 311,97 & 30 \\
\hline 550 & 288,89 & 30 & 464,58 & 35 & 468,1 & 35 \\
\hline 450 & 464,47 & 40 & 683,66 & 51 & 687,36 & 51 \\
\hline 350 & 727,93 & 70 & 1011,03 & 75 & 1015,57 & 75 \\
\hline 250 & 1205,96 & 120 & 1671,78 & 180 & 1675,28 & 180 \\
\hline
\end{tabular}

Największą pojemność użytkową zbiornik $Z R 2$ osiąga w przypadku zastosowania w zbiorniku $Z R 1$ układu grawitacyjno-pompowego (3), jednak mało różni się ona w porównaniu do pojemności zbiorników wielokomorowych grawitacyjnych. Istotne jest też to, że podane zależności obserwuje się przy wszystkich założonych wartościach natężenia odpływu ścieków ze zbiornika $Z R 2$.

Aby lepiej zobrazować wielkość wpływu przyjętego układu hydraulicznego w zbiorniku $Z R 1$ na wymaganą pojemność użytkową zbiornika $Z R 2$, wyznaczono różnice $\mathrm{w}$ pojemności użytkowej zbiornika $Z R 2$ przy różnych wariantach funkcjonowania zbiornika $Z R 1$ (tab. 5, 6 i 7).

Rozpatrując wyniki symulacji, które zamieszczono w tabelach 5, 6 i 7 należy stwierdzić, że różnica względna w pojemności użytkowej zbiornika $Z R 2$, wynikająca z zastosowania odmiennych układów hydraulicznych zbiornika $Z R 1$ zwiększa się wraz ze wzrostem natężenia odpływu ścieków $Q O_{Z R 2}$ ze zbiornika $Z R 2$. Zależność ta jest również potęgowana przez wartość natężenia odpływu ścieków $Q O_{Z R 2}$ ze zbiornika $Z R 1$. Im wyższą wartość przyjmie natężenie odpływu ścieków $Q O_{Z R 1}$, tym różnica względna w pojemności retencyjnej zbiornika $Z R 2$ przyjmuje wartość mniejszą. Okazuje się, że ustalone różnice procentowe wymaganej pojemności użytkowej zbiornika ZR2 mieszczą się w bardzo rozległym zakresie, od $0,01 \%$ (tab. 7) do 321,71\% (tab. 5). Najniższe procentowe 
różnice w pojemnościach zbiornika $Z R 2$, biorąc pod uwagę zróżnicowane układy hydrauliczne zbiornika $Z R 1$ zaobserwowano przy natężeniach odpływu ścieków ze zbiorników $Z R 2$ przy $Q O_{Z R 2}=250 \mathrm{dm}^{3} / \mathrm{s}$ i $Z R 1$ przy odpływie $Q O_{Z R 1}=750 \mathrm{dm}^{3} / \mathrm{s}$ (tab. 7, ostatni wiersz). Natomiast największe procentowe różnice w wymaganej pojemności użytkowej zbiornika $Z R 2$ stwierdzono przy natężeniach odpływu ścieków ze zbiorników $Z R 2$ o $Q O_{Z R 2}=950 \mathrm{dm}^{3} / \mathrm{s}$ i $Z R 1$ o $Q O_{Z R 1}=150 \mathrm{dm}^{3} / \mathrm{s}$ (tab. 5, wiersz 3). I co jest istotne, okazuje się, że w ostatnim przypadku zastosowanie w zbiorniku $Z R 1$ układu jednokomorowego (1) pozwala uniknąć zastosowania zbiornika $Z R 2$.

Tabela 3. Wymagana pojemność użytkowa zbiornika retencyjnego $Z R 2$ przy odpływie ścieków ze zbiornika $Z R 1$ o $Q O_{Z R 1}=450 \mathrm{dm}^{3} / \mathrm{s}$

Table 3. Required useable cubic capacity of storage reservoir $Z R 2$ at outflow from reservoir $Z R 1$ $Q O_{Z R 1}=450 \mathrm{dm}^{3} / \mathrm{s}$

\begin{tabular}{|c|c|c|c|c|c|c|}
\hline \multirow{3}{*}{$\begin{array}{l}\text { Maksymalne } \\
\text { natężenie od- } \\
\text { pływu ścieków } \\
\text { ze zbiornika } \\
Z R 2, Q O_{Z R 2}\end{array}$} & \multicolumn{6}{|c|}{$\begin{array}{c}\text { Użytkowa pojemność retencyjna zbiornika } Z R 2 \text { przy różnym układzie } \\
\text { hydraulicznym zbiornika retencyjnego } Z R 1\end{array}$} \\
\hline & \multicolumn{2}{|c|}{$\begin{array}{c}\text { Grawitacyjny } \\
\text { jednokomorowy (1) } \\
Z K\end{array}$} & \multicolumn{2}{|c|}{$\begin{array}{c}\text { Grawitacyjny } \\
\text { wielokomorowy (2) } \\
Z W G\end{array}$} & \multicolumn{2}{|c|}{$\begin{array}{c}\text { Grawitacyjno- } \\
\text {-pompowy } \\
\text { wielokomorowy (3) } \\
Z W G P\end{array}$} \\
\hline & $\begin{array}{l}V_{Z R 1} \\
(Z K)\end{array}$ & $\begin{array}{c}\text { Czas } \\
\text { krytyczny, } \\
\text { TMK }\end{array}$ & $\begin{array}{c}V_{Z R 1} \\
(Z W G)\end{array}$ & $\begin{array}{c}\text { Czas } \\
\text { krytyczny, } \\
T M W\end{array}$ & $\begin{array}{c}V_{Z R 1} \\
(Z W G P)\end{array}$ & $\begin{array}{c}\text { Czas } \\
\text { krytyczny, } \\
T M W P\end{array}$ \\
\hline$\left[\mathrm{dm}^{3} / \mathrm{s}\right]$ & {$\left[\mathrm{m}^{3}\right]$} & {$[\mathrm{min}]$} & {$\left[\mathrm{m}^{3}\right]$} & {$[\mathrm{min}]$} & {$\left[\mathrm{m}^{3}\right]$} & [min] \\
\hline 950 & 58,41 & 30 & 240,69 & 32 & 243,97 & 32 \\
\hline 850 & 151,41 & 35 & 384,17 & 37 & 388,07 & 37 \\
\hline 750 & 293,55 & 45 & 582,75 & 50 & 587,49 & 50 \\
\hline 650 & 502,41 & 56 & 866,05 & 71 & 872,7 & 71 \\
\hline 550 & 799,6 & 65 & 1263,86 & 85 & 1273,34 & 85 \\
\hline 450 & 1222,9 & 84 & 1732,8 & 90 & 1741,56 & 90 \\
\hline 350 & 1802,04 & 110 & 2255,6 & 91 & 2257,66 & 91 \\
\hline 250 & 2624,31 & 160 & 2922,95 & 135 & 2923,99 & 135 \\
\hline
\end{tabular}

Analizując występujące różnice w ustalonych pojemnościach retencyjnych obserwuje się też inną zależność. Najwyższą różnicę w wymaganej pojemności użytkowej zbiornika $Z R 2$ wynoszącą $509,9 \mathrm{~m}^{3}$ (tab. 6) ustalono, stosując układy hydrauliczne zbiorników (1) i (2), gdy natężenia odpływu ścieków ze zbiorników były sobie równe $Q O_{Z R 2}=Q O_{Z R 1}=450 \mathrm{dm}^{3} / \mathrm{s}$ (tab. 6). Przy tych samych wartościach natężenia odpływu ścieków ze zbiorników zaobserwowano również największą różnicę w wymaganej pojemności użytkowej zbiornika $Z R 2$ pomiędzy układem hydraulicznym (1) i (3), która wynosi 518,66 m³. Natomiast dokonując porównania układów hydraulicznych (2) i (3), najwyższą różnicę w wy- 
maganej pojemności zbiornika $Z R 2$ zaobserwowano przy odpływach $Q O_{Z R 2}=950 \mathrm{dm}^{3} / \mathrm{s}$ i $Q O_{Z R 1}=750 \mathrm{dm}^{3} / \mathrm{s}$ i wyniosła ona zaledwie $19,32 \mathrm{~m}^{3}$ (tab. 7).

Tabela 4. Wymagana pojemność użytkowa zbiornika retencyjnego $Z R 2$ przy odpływie ścieków ze zbiornika $Z R 1$ o $Q O_{Z R 1}=750 \mathrm{dm}^{3} / \mathrm{s}$

Table 4. Required useable cubic capacity of storage reservoir $Z R 2$ at outflow from reservoir $Z R 1$ $Q O_{Z R 1}=750 \mathrm{dm}^{3} / \mathrm{s}$

\begin{tabular}{|c|c|c|c|c|c|c|}
\hline \multirow{3}{*}{$\begin{array}{l}\text { Maksymalne } \\
\text { natężenie od- } \\
\text { pływu ścieków } \\
\text { ze zbiornika } \\
Z R 2, Q O_{Z R 2}\end{array}$} & \multicolumn{6}{|c|}{$\begin{array}{c}\text { Użytkowa pojemność retencyjna zbiornika } Z R 2 \text { przy różnym układzie } \\
\text { hydraulicznym zbiornika retencyjnego } Z R 1\end{array}$} \\
\hline & \multicolumn{2}{|c|}{$\begin{array}{c}\text { Grawitacyjny } \\
\text { jednokomorowy (1) } \\
Z K\end{array}$} & \multicolumn{2}{|c|}{$\begin{array}{c}\text { Grawitacyjny } \\
\text { wielokomorowy (2) } \\
Z W G\end{array}$} & \multicolumn{2}{|c|}{$\begin{array}{c}\text { Grawitacyjno- } \\
\text {-pompowy } \\
\text { wielokomorowy (3) } \\
Z W G P \\
\end{array}$} \\
\hline & $\begin{array}{l}V_{Z R 1} \\
(Z K)\end{array}$ & $\begin{array}{c}\text { Czas } \\
\text { krytyczny, } \\
T M K\end{array}$ & $\begin{array}{c}V_{Z R 1} \\
(Z W G)\end{array}$ & $\begin{array}{c}\text { Czas } \\
\text { krytyczny, } \\
T M W\end{array}$ & $\begin{array}{c}V_{Z R 1} \\
(Z W G P)\end{array}$ & $\begin{array}{c}\text { Czas } \\
\text { krytyczny, } \\
T M W P\end{array}$ \\
\hline$\left[\mathrm{dm}^{3} / \mathrm{s}\right]$ & {$\left[\mathrm{m}^{3}\right]$} & [min] & {$\left[\mathrm{m}^{3}\right]$} & [min] & {$\left[\mathrm{m}^{3}\right]$} & [min] \\
\hline 950 & 326,54 & 38 & 519,66 & 37 & 538,98 & 37 \\
\hline 850 & 499,91 & 40 & 706,4 & 39 & 718,66 & 39 \\
\hline 750 & 713,47 & 45 & 914,58 & 41 & 923,41 & 41 \\
\hline 650 & 973,54 & 51 & 1157,89 & 45 & 1159,96 & 45 \\
\hline 550 & 1285,88 & 60 & 1439,48 & 54 & 1440,97 & 54 \\
\hline 450 & 1677,51 & 71 & 1797,31 & 65 & 1798,35 & 65 \\
\hline 350 & 2169,8 & 96 & 2257,09 & 90 & 2257,68 & 90 \\
\hline 250 & 2864,42 & 140 & 2924,15 & 134 & 2924,56 & 134 \\
\hline
\end{tabular}

Po pełnej analizie danych z symulacji hydrodynamicznych (tabele $2 \div 7$ ) należy stwierdzić, że zastosowanie w zbiorniku górnym $Z R 1$ układu grawitacyjnopompowego (3) zwiększa tylko w niewielkim stopniu wymaganą pojemność użytkową zbiornika retencyjnego $Z R 2 \mathrm{w}$ odniesieniu do układu wielokomorowego działającego w systemie grawitacyjnym (2).

\subsection{Układ hydrauliczny a miarodajny czas trwania deszczu}

Wyniki badań symulacyjnych zamieszczone w tabelach 2, 3 i 4 potwierdzają kolejne prawidłowości. Okazuje się bowiem, że przyjęty układ hydrauliczny w zbiorniku retencyjnym $Z R 1$ wpływa bezpośrednio na długość miarodajnego czasu trwania deszczu (krytycznego) do wymiarowania zbiornika retencyjnego $Z R 2$. Przeprowadzone badania wykazały, że przy układach hydraulicznych (2) i (3) w zbiorniku $Z R 1$ obserwuje się identyczne wartości miarodajnego czasu trwania deszczu do wymiarowania wymaganej kubatury użytkowej zbiornika 
$Z R 2$. Natomiast w przypadku przyjęcia w zbiorniku $Z R 1$ układu hydraulicznego (1), miarodajny czasu trwania deszczu do wymiarowania wymaganej pojemności zbiornika $Z R 2$ osiąga inne wartości w stosunku do wcześniej wspomnianych układów hydraulicznych.

Należy zaznaczyć, że wzajemna relacja pomiędzy miarodajnym czasem trwania deszczu, ustalonym do wymiarowania zbiornika $Z R 2$ i przyjętym układem hydraulicznym w zbiorniku $Z R 1$ zmienia się w zależności od wartości maksymalnego natężenie odpływu ścieków $Q O_{Z R 1}$. Przy natężeniu odpływu ścieków ze zbiornika $Z R 1$ równym $Q O_{Z R 1}=150 \mathrm{dm}^{3} / \mathrm{s}$, czas miarodajny do wymiarowania zbiornika $Z R 2$, bez względu na przyjętą wartości natężenia odpływu ścieków $Q O_{Z R 2}$, przyjmuje każdorazowo wartość najniższą pod warunkiem, że zbiornik ZR1 wykonany jest w układzie jednokomorowym (1).

Jednak przy natężeniu odpływu ścieków ze zbiornika $Z R 1$ o wartości $Q O_{Z R 1}=450 \mathrm{dm}^{3} / \mathrm{s}$, wyżej wykazaną zależność obserwuje się wyłącznie przy natężeniu odpływu ścieków ze zbiornika $Z R 2$ o $Q O_{Z R 2} \geq 450 \mathrm{dm}^{3} / \mathrm{s}$. W przypadku pozostałych wartości natężenia odpływu ścieków ze zbiornika $Z R 2$, długość czasu miarodajnego do wyznaczania jego pojemności użytkowej przyjmuje wartość niższą w porównaniu do sytuacji, gdy zbiornik $Z R 1$ działa w układzie hydraulicznym (2) lub (3).

Tabela 5. Różnice w wymaganej pojemności użytkowej zbiornika $Z R 2$ przy odpływie ścieków ze zbiornika $Z R 1$ o $Q O_{Z R 1}=150 \mathrm{dm}^{3} / \mathrm{s}$

Table 5. Percentage differences in cubic capacity of reservoir $Z R 2$ at outflow from reservoir $Z R 1$ $Q O_{Z R 1}=150 \mathrm{dm}^{3} / \mathrm{s}$

\begin{tabular}{|c|c|c|c|c|c|c|c|c|c|}
\hline \multirow{2}{*}{$\begin{array}{l}\text { Maksymalne } \\
\text { natężenie } \\
\text { odpływu } \\
\text { ścieków } \\
\text { ze zbiornika } \\
Z R 2, Q O_{Z R 2}\end{array}$} & \multicolumn{3}{|c|}{$\begin{array}{c}\text { Wymagana pojemność } \\
\text { użytkowa zbiornika } Z R 2 \\
\text { przy układzie } \\
\text { hydraulicznym zbiornika } \\
\text { retencyjnego } Z R 1\end{array}$} & \multicolumn{3}{|c|}{$\begin{array}{l}\text { Różnica w wymaganej } \\
\text { pojemności użytkowej } \\
\text { zbiornika } Z R 2\end{array}$} & \multicolumn{3}{|c|}{$\begin{array}{c}\text { Różnica względna } \\
\text { w wymaganej pojemności } \\
\text { użytkowej zbiornika } Z R 2\end{array}$} \\
\hline & (1) & (2) & (3) & (2) - (1) & (3) - (1) & (3) - (2) & $\frac{(2)-(1)}{(1)}$ & $\frac{(3)-(1)}{(1)}$ & $\frac{(3)-(2)}{(2)}$ \\
\hline$\left[\mathrm{dm}^{3} / \mathrm{s}\right]$ & {$\left[\mathrm{m}^{3}\right]$} & {$\left[\mathrm{m}^{3}\right]$} & {$\left[\mathrm{m}^{3}\right]$} & {$\left[\mathrm{m}^{3}\right]$} & {$\left[\mathrm{m}^{3}\right]$} & {$\left[\mathrm{m}^{3}\right]$} & [\%] & [\%] & [\%] \\
\hline 950 & 0 & 44,44 & 46,44 & 44,44 & 46,44 & 2,00 & - & - & 4,50 \\
\hline 850 & 25,8 & 106,43 & 108,8 & 80,63 & 83,00 & 2,37 & 312,52 & 321,71 & 2,23 \\
\hline 750 & 83,37 & 193,33 & 196,07 & 109,96 & 112,7 & 2,74 & 131,89 & 135,18 & 1,42 \\
\hline 650 & 168,96 & 308,98 & 311,97 & 140,02 & 143,01 & 2,99 & 82,87 & 84,64 & 0,97 \\
\hline 550 & 288,89 & 464,58 & 468,1 & 175,69 & 179,21 & 3,52 & 60,82 & 62,03 & 0,76 \\
\hline 450 & 464,47 & 683,66 & 687,36 & 219,19 & 222,89 & 3,70 & 47,19 & 47,99 & 0,54 \\
\hline 350 & 727,93 & 1011,03 & 1015,57 & 283,1 & 287,64 & 4,54 & 38,89 & 39,51 & 0,45 \\
\hline 250 & 1205,96 & 1671,78 & 1675,28 & 465,82 & 469,32 & 3,5 & 38,63 & 38,92 & 0,21 \\
\hline
\end{tabular}


Tabela 6. Różnice w wymaganej pojemności użytkowej zbiornika $Z R 2$ przy odpływie ścieków ze zbiornika $Z R 1$ o $Q O_{Z R 1}=450 \mathrm{dm}^{3} / \mathrm{s}$

Table 6. Percentage differences in cubic capacity of reservoir $Z R 2$ at outflow from reservoir $Z R 1$ $Q O_{Z R 1}=450 \mathrm{dm}^{3} / \mathrm{s}$

\begin{tabular}{|c|c|c|c|c|c|c|c|c|c|}
\hline \multirow{2}{*}{$\begin{array}{l}\text { Maksymalne } \\
\text { natężenie } \\
\text { odpływu } \\
\text { ścieków } \\
\text { ze zbiornika } \\
Z R 2, Q O_{Z R 2}\end{array}$} & \multicolumn{3}{|c|}{$\begin{array}{l}\text { Wymagana pojemność } \\
\text { użytkowa zbiornika } Z R 2 \\
\text { przy układzie } \\
\text { hydraulicznym zbiornika } \\
\text { retencyjnego } Z R 1\end{array}$} & \multicolumn{3}{|c|}{$\begin{array}{l}\text { Różnica w wymaganej } \\
\text { pojemności użytkowej } \\
\text { zbiornika } Z R 2\end{array}$} & \multicolumn{3}{|c|}{$\begin{array}{c}\text { Różnica względna } \\
\text { w wymaganej pojemności } \\
\text { użytkowej zbiornika } Z R 2\end{array}$} \\
\hline & (1) & (2) & (3) & (2) - (1) & (3) - (1) & (3) - (2) & $\frac{(2)-(1)}{(1)}$ & $\frac{(3)-(1)}{(1)}$ & $\frac{(3)-(2)}{(2)}$ \\
\hline$\left[\mathrm{dm}^{3} / \mathrm{s}\right]$ & {$\left[\mathrm{m}^{3}\right]$} & {$\left[\mathrm{m}^{3}\right]$} & {$\left[\mathrm{m}^{3}\right]$} & {$\left[\mathrm{m}^{3}\right]$} & {$\left[\mathrm{m}^{3}\right]$} & {$\left[\mathrm{m}^{3}\right]$} & {$[\%]$} & {$[\%]$} & [\%] \\
\hline 950 & 58,41 & 240,69 & 243,97 & 182,28 & 185,56 & 3,28 & 312,07 & 317,69 & 1,36 \\
\hline 850 & 151,41 & 384,17 & 388,07 & 232,76 & 236,66 & 3,9 & 153,73 & 156,30 & 1,02 \\
\hline 750 & 293,55 & 582,75 & 587,49 & 289,2 & 293,94 & 4,74 & 98,52 & 100,13 & 0,81 \\
\hline 650 & 502,41 & 866,05 & 872,7 & 363,64 & 375,69 & 6,65 & 72,38 & 74,78 & 0,77 \\
\hline 550 & 799,6 & 1263,86 & 1273,34 & 464,26 & 473,74 & 9,48 & 58,06 & 59,25 & 0,75 \\
\hline 450 & 1222,9 & 1732,8 & 1741,56 & 509,9 & 518,66 & 8,76 & 41,70 & 42,41 & 0,51 \\
\hline 350 & 1802,04 & 2255,6 & 2257,66 & 453,56 & 455,62 & 2,06 & 25,17 & 25,28 & 0,09 \\
\hline 250 & 2624,31 & 2922,95 & 2923,99 & 298,64 & 299,68 & 1,04 & 11,38 & 11,42 & 0,04 \\
\hline
\end{tabular}

Tabela 7. Różnice w wymaganej pojemności użytkowej zbiornika $Z R 2$, przy odpływie ścieków ze zbiornika $Z R 1$ o $Q O_{Z R 1}=750 \mathrm{dm}^{3} / \mathrm{s}$

Table 7. Percentage differences in cubic capacity of reservoir $Z R 2$ at outflow from reservoir $Z R 1$ $Q O_{Z R 1}=750 \mathrm{dm}^{3} / \mathrm{s}$

\begin{tabular}{|c|c|c|c|c|c|c|c|c|c|}
\hline \multirow{2}{*}{$\begin{array}{c}\text { Maksymalne } \\
\text { natężenie } \\
\text { odpływu } \\
\text { ścieków } \\
\text { ze zbiornika } \\
Z R 2, Q O_{Z R 2}\end{array}$} & \multicolumn{3}{|c|}{$\begin{array}{c}\text { Wymagana pojemność } \\
\text { użytkowa zbiornika } Z R 2 \\
\text { przy układzie } \\
\text { hydraulicznym zbiornika } \\
\text { retencyjnego } Z R 1\end{array}$} & \multicolumn{3}{|c|}{$\begin{array}{l}\text { Różnica w wymaganej } \\
\text { pojemności użytkowej } \\
\text { zbiornika } Z R 2\end{array}$} & \multicolumn{3}{|c|}{$\begin{array}{c}\text { Różnica względna w wyma- } \\
\text { ganej pojemności użytkowej } \\
\text { zbiornika } Z R 2\end{array}$} \\
\hline & (1) & (2) & (3) & (2) - (1) & (3) - (1) & (3) - (2) & $\frac{(2)-(1)}{(1)}$ & $\frac{(3)-(1)}{(1)}$ & $\frac{(3)-(2)}{(2)}$ \\
\hline$\left[\mathrm{dm}^{3} / \mathrm{s}\right]$ & {$\left[\mathrm{m}^{3}\right]$} & {$\left[\mathrm{m}^{3}\right]$} & {$\left[\mathrm{m}^{3}\right]$} & {$\left[\mathrm{m}^{3}\right]$} & {$\left[\mathrm{m}^{3}\right]$} & {$\left[\mathrm{m}^{3}\right]$} & {$[\%]$} & {$[\%]$} & {$[\%]$} \\
\hline 950 & 326,54 & 519,66 & 538,98 & 193,12 & 212,44 & 19,32 & 59,14 & 65,06 & 3,72 \\
\hline 850 & 499,91 & 706,4 & 718,66 & 206,49 & 218,75 & 12,26 & 41,31 & 43,76 & 1,74 \\
\hline 750 & 713,47 & 914,58 & 923,41 & 201,11 & 209,94 & 8,83 & 28,19 & 29,43 & 0,97 \\
\hline 650 & 973,54 & 1157,89 & 1159,96 & 184,35 & 186,42 & 2,07 & 18,94 & 19,15 & 0,18 \\
\hline 550 & 1285,88 & 1439,48 & 1440,97 & 153,6 & 155,09 & 1,49 & 11,95 & 12,06 & 0,10 \\
\hline 450 & 1677,51 & 1797,31 & 1798,35 & 119,8 & 120,84 & 1,04 & 7,14 & 7,20 & 0,06 \\
\hline 350 & 2169,8 & 2257,09 & 2257,68 & 87,29 & 87,88 & 0,59 & 4,02 & 4,05 & 0,03 \\
\hline 250 & 2864,42 & 2924,15 & 2924,56 & 59,73 & 60,14 & 0,41 & 2,09 & 2,10 & 0,01 \\
\hline
\end{tabular}


Analizując działanie zbiornika $Z R 1$ przy odpływie $Q O_{Z R 1}=750 \mathrm{dm}^{3} / \mathrm{s}$ ustalono sytuację odwrotną niż miała miejsce przy $Q O_{Z R 1}=150 \mathrm{dm}^{3} / \mathrm{s}$. W tym przypadku najniższe wartości miarodajnego czasu trwania deszczu dla całego zakresu natężenia odpływu ścieków $Q O_{Z R 2}$ ze zbiornika $Z R 2$ obserwuje się, gdy zbiornik retencyjny $Z R 1$ działa w systemie jednokomorowym (1).

Opierając się na wynikach badań symulacyjnych sieci w dwóch zlewniach posiadających kanalizacją deszczową a na wylotach zbiorniki retencyjne należy stwierdzić, że na wartość miarodajnego czasu trwania deszczu do wymiarowania zbiornika $Z R 2$ usytuowanego niżej w systemie kanalizacyjnym wpływa zarówno układ hydrauliczny, jak i maksymalna przyjęta wartość natężenia odpływu ścieków ze zbiornika $Z R 1$ zlokalizowanego na końcu zlewni $F 1$.

\subsection{Układ hydrauliczny a czas odpływu ścieków}

Do badań celowo przyjęto zlewnie i układ sieci deszczowej taki, aby ścieki odpływające ze zbiornika $Z R 1$ miały udział w bilansie ścieków dopływających do zbiornika $Z R 2$. Otrzymane różnice w pojemności użytkowej zbiornika retencyjnego $Z R 2$ wynikają z odmiennego przebiegu natężenia odpływu ścieków ze zbiornika $Z R 1$. Charakterystyka odpływu ścieków ze zbiornika $Z R 1 \mathrm{w}$ postaci hydrogramu odpływu zależy przede wszystkim od jego układu hydraulicznego. Przebieg zmienności natężenia odpływu ścieków ze zbiornika $Z R 1 \mathrm{w}$ kierunku komory przepływowej zbiornika $Z R 2$ przy uwzględnieniu różnych układów hydraulicznych zbiornika $Z R 1$, biorąc pod uwagę odmienne warianty projektowe badanej sieci kanalizacyjnej przedstawiono na rysunku 2.

Jak wykazano istnieje wiele kryteriów, które w zróżnicowanym stopniu wpływają na wybór wymaganej pojemności użytkowej zbiorników zlokalizowanych na końcu zlewni górnej $F 1$ i dolnej zlewni $F 2$.

Analizując krzywe zamieszczone na rysunku 2 można wykazać, że najkrótszym czasem odpływu ścieków charakteryzuje się zbiornik grawitacyjnopompowy. Zastosowanie $\mathrm{w}$ zbiorniku górnym $Z R 1$ układu hydraulicznego o wysokiej efektywności ((2) i (3)) zapewni odpływ ścieków z tych zbiorników na ustalonym stałym poziomie, praktycznie prawie w całym okresie ich retencji, gdy natężenie dopływu będzie równe lub większe od natężenia ich odpływu.

Okazuje się, że większy odpływ ścieków ze zbiornika górnego $Z R 1$ będzie skutkował zwiększeniem wymaganej kubatury zbiornika zlokalizowanego poniżej $Z R 2$, co przedstawiają wyniki symulacji zamieszczone w tabelach od 2 do 7 . Natomiast co było do przewidzenia, zastosowanie układu hydraulicznego zbiornika jednokomorowego, pomimo że odzwierciedla najdłuższy czas odpływu $\mathrm{z}$ niego ścieków, to jednak korzystnie oddziałuje na ich akumulację w zbiorniku $Z R 2$, gdyż osiąga on mniejszą wymaganą pojemność użytkową.

Przy współdziałaniu sieci kanalizacyjnej z więcej niż jednym zbiornikiem retencyjnym, wymiernym parametrem decydującym o efektywności systemu kanalizacyjnego jest całkowita pojemność retencyjna wszystkich zbiorników 
wchodzących w jego skład. W tabelach 8,9 i 10 przedstawiono sumaryczną pojemność użytkową zbiorników $Z R 1$ i $Z R 2$ uzyskaną przy wszystkich przyjętych wariantach projektowych.

a)

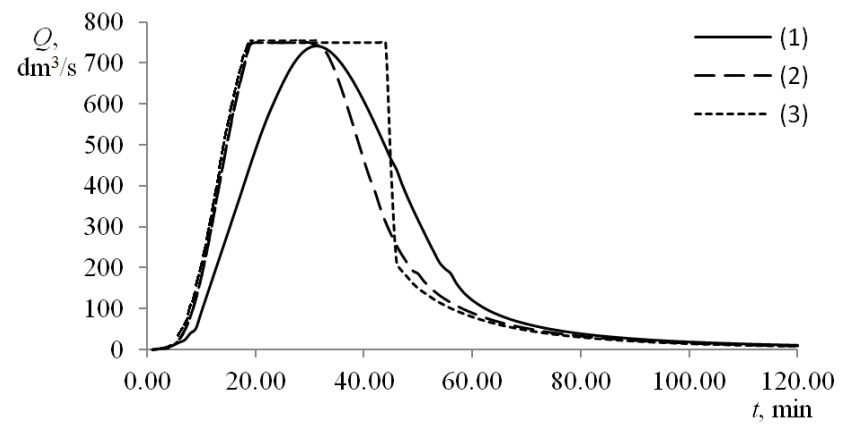

b)

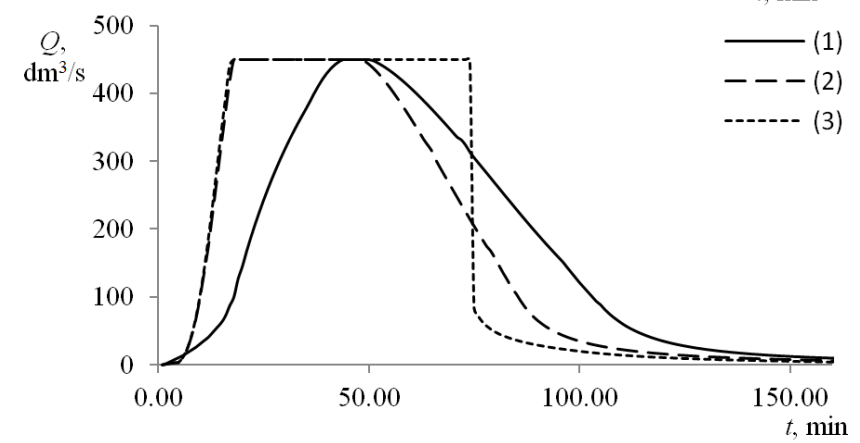

c)

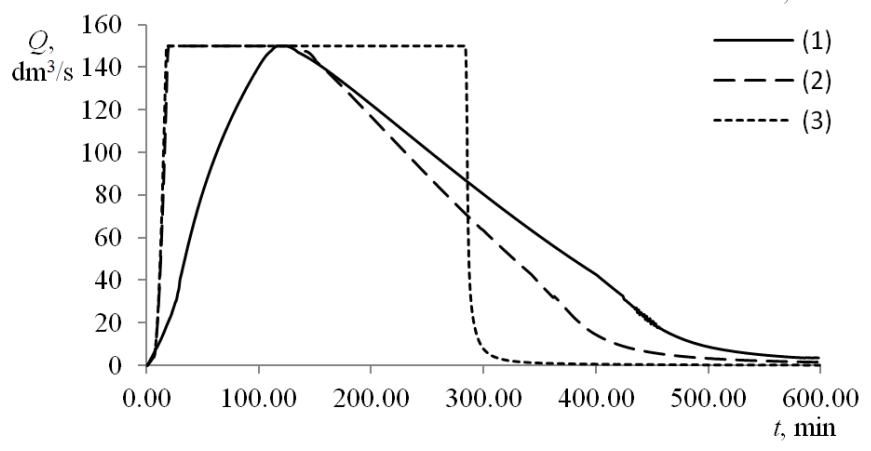

Rys. 2. Hydrogramy odpływu ścieków ze zbiornika górnego $Z R 1$ przy: a) maksymalnej wartości odpływu ścieków $Q O_{Z R 1}=750 \mathrm{dm}^{3} / \mathrm{s}$ i czasie trwania deszczu $t_{d}=30 \mathrm{~min}$, b) maksymalnej wartości odpływu ścieków $Q O_{Z R 1}=450 \mathrm{dm}^{3} / \mathrm{s}$ i czasie trwania deszczu $t_{d}=50 \mathrm{~min}$, c) maksymalnej wartości odpływu ścieków $Q O_{Z R 1}=150 \mathrm{dm}^{3} / \mathrm{s}$ i czasie trwania deszczu $t_{d}=120 \mathrm{~min}$ : 1 - układ hydrauliczny zbiornika jako grawitacyjny jednokomorowy $Z K, 2$ - układ hydrauliczny zbiornika jako grawitacyjny wielokomorowy $Z W G, 3$ - układ hydrauliczny zbiornika jako grawitacyjno-pompowy $Z W G P$

Fig. 2. Hydrographs of wastewater outflow from reservoir $Z R 1$ at: a) maximum outflow $Q O_{Z R 1}=750 \mathrm{dm}^{3} / \mathrm{s}$ and duration of rainfall $\left.t_{d}=30 \mathrm{~min}, \mathrm{~b}\right)$ maximum outflow $Q O_{Z R 1}=450 \mathrm{dm}^{3} / \mathrm{s}$ and duration of rainfall $t_{d}=50 \mathrm{~min}$, c) maximum outflow $Q O_{Z R 1}=150 \mathrm{dm}^{3} / \mathrm{s}$ and duration of rainfall $t_{d}=120 \mathrm{~min}: 1$ - gravitational one-chamber reservoir $Z K, 2$ - gravitational multi-chamber reservoir $Z W G$, 3 - gravity-pump multi-chamber reservoir $Z W G P$ 
Z porównania wyników badań zamieszczonych w tabelach od 8 do 10 wynika, że układ hydrauliczny zbiornika $Z R 1$, który wymaga $\mathrm{z}$ reguły najmniejszej wymaganej pojemności użytkowej jest zbiornik z układem grawitacyjnym wielokomorowym (2). Tylko $w$ trzech wariantach projektowych zastosowanie w zbiorniku $Z R 1$ układu hydraulicznego jednokomorowego pozwoliło osiągnąć najmniejszą łączną pojemność użytkową układu zbiorników retencyjnych $Z R 1$ i ZR2 (tabela 9).

Ustalone różnice procentowe $\mathrm{w}$ pojemności użytkowej układu zbiorników retencyjnych przy uwzględnieniu 72 różnych wariantów projektowych mieszczą się w przedziale od $0,01 \%$ do $23,31 \%$.

Najmniejszą różnicę w sumarycznej pojemności użytkowej zbiorników zlokalizowanych na założonych zlewniach zaobserwowano porównując ze sobą układy hydrauliczne (2) i (3) w zbiorniku $Z R 1$, gdy odpływ ścieków ze zbiorników był równy kolejno $Q O_{Z R 1}=750 \mathrm{dm}^{3} / \mathrm{s}$ i $Q O_{Z R 2}=250 \mathrm{dm}^{3} / \mathrm{s}$. Natomiast największą różnicę w wymaganej kubaturze użytkowej układu zbiorników retencyjnych zauważono zestawiając ze sobą układy hydrauliczne (1) i (2) w zbiorniku $Z R 1$, gdy maksymalna ilość odpływających ścieków ze zbiorników wynosiła odpowiednio $Q O_{Z R 1}=150 \mathrm{dm}^{3} / \mathrm{s}$ i $Q O_{Z R 2}=950 \mathrm{dm}^{3} / \mathrm{s}$. Z kolei różnice w pojemności użytkowej układu zbiorników retencyjnych wyrażone w metrach sześciennych zawierają się w przedziale od 0,41 do $415,54 \mathrm{~m}^{3}$.

Tabela 8. Całkowita pojemność użytkowa układu zbiorników retencyjnych $Z R 1$ i $Z R 2$ przy $Q O_{Z R 1}=150 \mathrm{dm}^{3} / \mathrm{s}$ i zmiennych odpływach $Q O_{Z R 2}$

Table 8. The total usable cubic capacity of reservoirs $Z R 1$ and $Z R 2$ at $Q O_{Z R 1}=150 \mathrm{dm}^{3} / \mathrm{s}$ and variable outflows $Q O_{Z R 2}$

\begin{tabular}{|c|c|c|c|c|c|c|c|c|c|}
\hline $\begin{array}{c}\text { Maksymalne } \\
\text { natężenie } \\
\text { odpływu } \\
\text { ścieków } \\
\text { ze zbiornika } \\
Z R 2, Q O_{Z R 2}\end{array}$ & $\begin{array}{c}\text { użytkowa układu zbiorników } \\
\text { retencyjnych przy różnym } \\
\text { układzie hydraulicznym } \\
\text { zbiornika retencyjnego } Z R 1\end{array}$ & \multicolumn{2}{|c|}{$\begin{array}{c}\text { Różnica w wymaganej } \\
\text { pojemności użytkowej } \\
\text { układu zbiorników } \\
\text { retencyjnych } Z R 1 \text { i } Z R 2\end{array}$} & \multicolumn{3}{|c|}{$\begin{array}{c}\text { Różnica względna } \\
\text { w wymaganej kubaturze } \\
\text { użytkowej układu zbiorników } \\
\text { retencyjnych ZR1 i } Z R 2\end{array}$} \\
\hline$\left[\mathrm{dm}^{3} / \mathrm{s}\right]$ & {$[1)$} & $(2)$ & $(3)$ & $(2)-(1)$ & $(3)-(1)$ & $(3)-(2)$ & $\frac{(2)-(1)}{(1)}$ & $\frac{(3)-(1)}{(1)}$ & $\frac{(3)-(2)}{(2)}$ \\
\hline 950 & 1783,05 & $\mathbf{1 3 6 7 , 5 1}$ & 1369,51 & $-415,54$ & $-413,54$ & 2,00 & $-23,31$ & $-23,19$ & 0,15 \\
\hline 850 & 1808,85 & $\mathbf{1 4 2 9 , 5 0}$ & 1431,87 & $-379,35$ & $-376,98$ & 2,37 & $-20,97$ & $-20,84$ & 0,17 \\
\hline 750 & 1866,42 & $\mathbf{1 5 1 6 , 4 0}$ & 1519,14 & $-350,02$ & $-347,28$ & 2,74 & $-18,75$ & $-18,61$ & 0,18 \\
\hline 650 & 1952,01 & $\mathbf{1 6 3 2 , 0 5}$ & 1635,04 & $-319,96$ & $-316,97$ & 2,99 & $-16,39$ & $-16,24$ & 0,18 \\
\hline 550 & 2071,94 & $\mathbf{1 7 8 7 , 6 5}$ & 1791,17 & $-284,29$ & $-280,77$ & 3,52 & $-13,72$ & $-13,55$ & 0,20 \\
\hline 450 & 2247,52 & $\mathbf{2 0 0 6 , 7 3}$ & 2010,43 & $-240,79$ & $-237,09$ & 3,70 & $-10,71$ & $-10,55$ & 0,18 \\
\hline 350 & 2510,98 & $\mathbf{2 3 3 4 , 1 0}$ & 2338,64 & $-176,88$ & $-172,34$ & 4,54 & $-7,04$ & $-6,86$ & 0,19 \\
\hline 250 & 2989,01 & $\mathbf{2 9 9 4 , 8 5}$ & 2998,35 & 5,84 & 9,34 & 3,50 & 0,20 & 0,31 & 0,12 \\
\hline
\end{tabular}


Tabela 9. Całkowita pojemność użytkowa układu zbiorników retencyjnych $Z R 1$ i $Z R 2$ przy $Q O_{Z R 1}=450 \mathrm{dm}^{3} / \mathrm{s}$ i zmiennych odpływach $Q O_{Z R 2}$

Table 9. The total capacity of reservoirs $Z R 1$ and $Z R 2$ at $Q O_{Z R 1}=450 \mathrm{dm}^{3} / \mathrm{s}$ and variable outflows $Q O_{Z R 2}$

\begin{tabular}{|c|c|c|c|c|c|c|c|c|c|}
\hline \multirow{2}{*}{$\begin{array}{l}\text { Maksymalne } \\
\text { natężenie } \\
\text { odpływu } \\
\text { ścieków ze } \\
\text { zbiornika } \\
Z R 2, Q O_{Z R 2}\end{array}$} & \multicolumn{3}{|c|}{$\begin{array}{l}\text { Wymagana pojemność } \\
\text { użytkowa układu } \\
\text { zbiorników retencyjnych } \\
\text { przy różnym układzie } \\
\text { hydraulicznym zbiornika } \\
\text { retencyjnego } Z R 1\end{array}$} & \multicolumn{3}{|c|}{$\begin{array}{l}\text { Różnica w wymaganej } \\
\text { pojemności użytkowej } \\
\text { układu zbiorników } \\
\text { retencyjnych } Z R 1 \text { i } Z R 2\end{array}$} & \multicolumn{3}{|c|}{$\begin{array}{c}\text { Różnica względna } \\
\text { w wymaganej kubaturze } \\
\text { użytkowej układu zbiorników } \\
\text { retencyjnych } Z R 1 \text { i } Z R 2\end{array}$} \\
\hline & (1) & (2) & (3) & (2) - (1) & (3) - (1) & (3) - (2) & $\frac{(2)-(1)}{(1)}$ & $\frac{(3)-(1)}{(1)}$ & $\frac{(3)-(2)}{(2)}$ \\
\hline$\left[\mathrm{dm}^{3} / \mathrm{s}\right]$ & {$\left[\mathrm{m}^{3}\right]$} & {$\left[\mathrm{m}^{3}\right]$} & {$\left[\mathrm{m}^{3}\right]$} & {$\left[\mathrm{m}^{3}\right]$} & {$\left[\mathrm{m}^{3}\right]$} & {$\left[\mathrm{m}^{3}\right]$} & {$[\%]$} & {$[\%]$} & {$[\%]$} \\
\hline 950 & 840,56 & 658,25 & 661,53 & $-182,31$ & $-179,03$ & 3,28 & $-21,69$ & $-21,30$ & 0,50 \\
\hline 850 & 933,56 & 801,73 & 805,63 & $-131,83$ & $-127,93$ & 3,90 & $-14,12$ & $-13,70$ & 0,49 \\
\hline 750 & 1075,70 & 1000,31 & 1005,05 & $-75,39$ & $-70,65$ & 4,74 & $-7,01$ & $-6,57$ & 0,47 \\
\hline 650 & 1284,56 & 1283,61 & 1295,66 & $-0,95$ & 11,10 & 12,05 & $-0,07$ & 0,86 & 0,94 \\
\hline 550 & 1581,75 & 1681,42 & 1690,90 & 99,67 & 109,15 & 9,48 & 6,30 & 6,90 & 0,56 \\
\hline 450 & 2005,05 & 2150,36 & 2159,12 & 145,31 & 154,07 & 8,76 & 7,25 & 7,68 & 0,41 \\
\hline 350 & 2584,19 & 2673,16 & 2675,22 & 88,97 & 91,03 & 2,06 & 3,44 & 3,52 & 0,08 \\
\hline 250 & 3406,46 & 3340,51 & 3341,55 & $-65,95$ & $-64,91$ & 1,04 & $-1,94$ & $-1,91$ & 0,03 \\
\hline
\end{tabular}

Tabela 10. Całkowita pojemność użytkowa układu zbiorników retencyjnych $Z R 1$ i $Z R 2$ przy $Q O_{Z R 1}=750 \mathrm{dm}^{3} / \mathrm{s}$ i zmiennych odpływach $Q O_{Z R 2}$

Table 10. The total capacity of reservoirs $Z R 1$ and $Z R 2$ at $Q O_{Z R 1}=750 \mathrm{dm}^{3} / \mathrm{s}$ and variable outflows $Q O_{Z R 2}$

\begin{tabular}{|c|c|c|c|c|c|c|c|c|c|}
\hline \multirow{2}{*}{$\begin{array}{l}\text { Maksymalne } \\
\text { natężenie } \\
\text { odpływu } \\
\text { ścieków } \\
\text { ze zbiornika } \\
Z R 2, Q_{o d p, Z R 2}\end{array}$} & \multicolumn{3}{|c|}{$\begin{array}{l}\text { Wymagana pojemność } \\
\text { użytkowa układu zbiorników } \\
\text { retencyjnych przy różnym } \\
\text { układzie hydraulicznym } \\
\text { zbiornika retencyjnego } Z R 1\end{array}$} & \multicolumn{3}{|c|}{$\begin{array}{l}\text { Różnica w wymaganej } \\
\text { pojemności użytkowej } \\
\text { układu zbiorników } \\
\text { retencyjnych } Z R 1 \text { i } Z R 2\end{array}$} & \multicolumn{3}{|c|}{$\begin{array}{c}\text { Różnica względna } \\
\text { w wymaganej kubaturze } \\
\text { użytkowej układu zbiorników } \\
\text { retencyjnych } Z R 1 \text { i } Z R 2\end{array}$} \\
\hline & (1) & (2) & (3) & (2) - (1) & (3) - (1) & (3) - (2) & $\frac{(2)-(1)}{(1)}$ & $\frac{(3)-(1)}{(1)}$ & $\frac{(3)-(2)}{(2)}$ \\
\hline$\left[\mathrm{dm}^{3} / \mathrm{s}\right]$ & {$\left[\mathrm{m}^{3}\right]$} & {$\left[\mathrm{m}^{3}\right]$} & {$\left[\mathrm{m}^{3}\right]$} & {$\left[\mathrm{m}^{3}\right]$} & {$\left[\mathrm{m}^{3}\right]$} & {$\left[\mathrm{m}^{3}\right]$} & {$[\%]$} & {$[\%]$} & [\%] \\
\hline 950 & 693,82 & 629,70 & 649,02 & $-64,12$ & $-44,80$ & 19,32 & $-9,24$ & $-6,46$ & 3,07 \\
\hline 850 & 867,19 & 816,44 & 828,70 & $-50,75$ & $-38,49$ & 12,26 & $-5,85$ & $-4,44$ & 1,50 \\
\hline 750 & 1080,75 & 1024,62 & 1033,45 & $-56,13$ & $-47,30$ & 8,83 & $-5,19$ & $-4,38$ & 0,86 \\
\hline 650 & 1340,82 & 1267,93 & 1270,00 & $-72,89$ & $-70,82$ & 2,07 & $-5,44$ & $-5,28$ & 0,16 \\
\hline 550 & 1653,16 & 1549,52 & 1551,01 & $-103,64$ & $-102,15$ & 1,49 & $-6,27$ & $-6,18$ & 0,10 \\
\hline 450 & 2044,79 & 1907,35 & 1908,39 & $-137,44$ & $-136,40$ & 1,04 & $-6,72$ & $-6,67$ & 0,05 \\
\hline 350 & 2537,08 & 2367,13 & 2367,72 & $-169,95$ & $-169,36$ & 0,59 & $-6,70$ & $-6,68$ & 0,02 \\
\hline 250 & 3231,70 & 3034,19 & 3034,60 & $-197,51$ & $-197,10$ & 0,41 & $-6,11$ & $-6,10$ & 0,01 \\
\hline
\end{tabular}




\section{Podsumowanie}

Wyniki przeprowadzonych badań modelowych pozwalają na sformułowanie szeregu istotnych wniosków o znaczeniu ogólnym i praktycznym. W wyniku przeprowadzonych symulacji wykazano, że układ hydrauliczny zbiornika retencyjnego $Z R 1$ zlokalizowanego powyżej na sieci ma bezpośredni wpływ na wymaganą pojemność użytkową zbiornika retencyjnego $Z R 2$ zlokalizowanego poniżej. Na podstawie wyników symulacji komputerowych, że zbiornik $Z R 2$ osiąga najmniejszą pojemność użytkową, gdy zbiornik górny $Z R 1$ jest jednokomorowy. Zależność ta występuje dla całego zakresu zmiennych wartości natężenia odpływu ścieków ze zbiornika dolnego $Z R 2$. Ponadto, im większą wartość przyjmuje natężenie odpływu ścieków ze zbiornika dolnego $Z R 2$, tym różnica względna w wymaganej pojemności użytkowej tego zbiornika pomiędzy analizowanymi trzema odmiennymi układami hydraulicznymi w zbiorniku górnym staje się większa.

W pracy wykazano także, że układ hydrauliczny w zbiorniku górnym $Z R 1$ wpływa bezpośrednio na miarodajny (krytyczny) czas trwania deszczu ustalany do wymiarowania zbiornika dolnego $Z R 2$. Udowodniono, że najkrótszy czas miarodajny do wymiarowania zbiornika dolnego $Z R 2$ może wystąpić przy wszystkich układach hydraulicznych zbiornika górnego i jest zależna od wartości parametrów charakteryzujących zredukowany odpływ ścieków ze zbiorników zlokalizowanych na sieci kanalizacyjnej.

W pracy wykazano również, że prowadząc optymalizację układu zbiorników retencyjnych należy uwzględniać oddziaływanie modeli hydraulicznych zbiorników górnych na pojemność użytkową zbiornika dolnego. Na podstawie przeprowadzonych badań ustalono, że zastosowanie w zbiorniku górnym konstrukcji grawitacyjnej wielokomorowej pozwala na osiągniecie w zdecydowanej większości przypadków najmniejszej łącznej pojemności użytkowej układu zbiorników retencyjnych.

Przeprowadzone badania potwierdzają słuszność postawionej tezy oraz umacniają w przekonaniu, że wymiarowanie układu zbiorników retencyjnych na sieci kanalizacyjnej jest zadaniem złożonym i wymaga uwzględnienia szczegółowych obliczeń i badań symulacyjnych w warunkach dynamicznych. Zakres ten obejmuje badanie przebiegu zjawisk obejmujących między innymi charakterystykę opadu, zlewni i kanalizacji, modelowanie przepływu w sieci i w zbiornikach retencyjnych o różnych układach hydraulicznych w celu wyboru optymalnego wariantu projektowego.

\section{Literatura}

[1] Błaszczyk W., Stamatello P., Roman M.: Kanalizacja T1, Wydawnictwo Arkady, Warszawa 1974.

[2] Bolt A., Burszta-Adamiak E., i inni.: Kanalizacja. Projektowanie, wykonanie, 
eksploatacja, Wydawnictwo Seidel - Przywecki, 2012.

[3] Dziopak J.: Analiza teoretyczna i modelowanie wielokomorowych zbiorników kanalizacyjnych, Monografia 125, Wyd. Politechniki Krakowskiej, Kraków 1992.

[4] Dziopak J., Słyś D.: Modelowanie zbiorników klasycznych i grawitacyjnopompowych w kanalizacji, Oficyna Wydawnicza PRz, Rzeszów 2007.

[5] Dziopak J., Starzec M.: Wpływ kierunki i prędkości fali deszczu na kubaturę uzytkową wielokomorowych zbiorników retencyjnych, Czasopismo Inżynierii Lądowej, Środowiska i Architektury JCEEA, nr 61 (3-1-14), 2014, s. 83-93.

[6] Kisiel A.: Przegląd najnowszych rozwiązań zbiorników kanalizacyjnych. Część I - Zbiorniki retencyjne, Gaz, Woda i Technika Sanitarna, Wydawnictwo SIGMA-NOT, nr 5, Warszawa 2000, s. 182-186.

[7] Kordana S., Słyś D.: Analiza kosztów cyklu życia skrzynek rozsączających, Czasopismo Inżynierii Lądowej, Środowiska i Architektury JCEEA, nr 61 (3/I/14), 2014, s. 127-139.

[8] Pochwat K.: Analysis of critical rainfall for dimensioning of sewage networks and storage reservoirs, IX Karpat - Medencei Kornyezettudomanyi Konferencia, 2013, s. $453-458$.

[9] Słyś D., Stec A.: Effect of development of the town of Przemyśl on the operation of its sewerage system, Ecological Chemistry and Engineering S, no. 20(2), 2013, s. 381-396.

\section{INFLUENCE OF HYDRAULIC MODEL OF RESERVOIR ON THE REQUIRED USABLE CAPACITY OF THE SYSTEM OF STORAGE RESERVOIRS IN SEWAGE SYSTEM}

\section{S u m m a r y}

The aim of this article is to determine the effect of the hydraulic system used in storage reservoir located at the end of the catchment area situated above on the required usable cubic capacity of multi-storage reservoir located at the end of the catchment area located below. Simulations of flow and accumulation of sewage were made for model catchment using hydrodynamic program SWMM 5.1. The results of model tests have shown that the hydraulic system of reservoir $Z R 1$ located above in sewage network has a decisive influence on the determination of the required usable volume of storage reservoir $Z R 2$ located lower in the network. Comparing the results of the research it has been shown that the reservoir $Z R 2$ has the smallest usable capacity, while the upper reservoir $Z R 1$ has a single chamber hydraulic system. The obtained differences in the retention capacity of the lower reservoir $Z R 2$ reach tens of percent, and in extreme cases, much more. The relationship observed for a wide range of variable intensity of the effluent from reservoirs $Z R 1$ ZR2 was established.

Keywords: rainwater drainage, reservoirs, hydraulic systems, dimensioning

DOI: $10.7862 / \mathrm{rb} .2016 .153$

Przestano do redakcji: 01.05.2016 $r$.

Przyjęto do druku: 28.06.2016 $r$. 